\title{
Undetected prevalence of urinary incontinence among middle-aged women and its association with quality of life
}

\author{
Incilay Çelik ${ }^{1}$, Ayse Kilic Ucar², Ümüt Güzelküçük ${ }^{3}$ \\ ${ }^{l}$ Gaziler Physical Medicine and Rehabilitation Training and Research Hospital, Ankara, Turkey \\ ${ }^{2}$ Florence Nightingale Hospital School of Nursing, Demiroglu Bilim University, Istanbul, Turkey \\ ${ }^{3}$ Gaziler Physical Medicine and Rehabilitation Training and Research Hospital, Ankara, Turkey
}

Received: 2021-07-05.

Accepted: 2021-09-21

This work is licensed under a Creative Commons Attribution 4.0 International License

J Clin Med Kaz 2021; 18(6):56-61

Corresponding author:

Incilay Çelik.

E-mail: incilay-mercan-92@hotmail.com;

ORCID: 0000-0002-1513-3469

\begin{abstract}
Introduction: The study was conducted to determine the undiagnosed prevalence of urinary incontinence and its association with the quality of life in middle-aged and older women.

Material and methods: The sample of the study consisted of women aged 40 years or above who were admitted to a tertiary care center between March and July 2019. The data were collected by faceto-face interview method. "International Consultation on Incontinence Questionnaire-Short Form (ICIQ-SF)" and "Incontinence Quality of Life Questionnaire (I-QOL)" were used to collect data on urinary incontinence and quality of life.

Results: The screened sample included 140 women (mean age: $60.6 \pm 11.3$ years). Urinary incontinence was detected in 90 subjects (64.3\%). Urinary incontinence complaints were present for an average of four years. Self-rated effect on daily life was moderate (ICIQ-SF: 5.0 \pm 2.5 ), and more than half of them (64.4\%) did not consider urinary incontinence as a health issue, More than half (62.9\%) did not admit for professional care for many reasons. The average score was $85.0 \pm 14.7$ from the "Psychosocial influence" sub-dimension, 71.0 \pm 16.9 from the "Social isolation" subdimension, 65.1 16.6 from the "Limitation of behaviors" sub-dimension, and $74.6 \pm 14.5$ from the whole scale. There was no significant relationship between I-QOL total score and educational status, marital status, income level, chronic diseases, mode of delivery, and menopause.

Discussion and conclusion: This study found that more than half of women admitted to a hospital for other reasons have urinary incontinence complaints. Although the duration of symptoms was long and quality of life was somehow influenced, admission to a health facility was low.
\end{abstract} health

Key words: urinary incontinence, quality of life, nursing, women's

\section{Introduction}

Urinary Incontinence (UI) is defined as "the complaint of involuntary UI regardless of the amount" (International Incontinence Association). UI affects people of all ages and genders. However, it is two times more common among women and older individuals $[1,2]$. The global prevalence of UI varies between $20 \%$ and $68 \%$ [35], while several studies from Turkey showed $40 \%$ to $60 \%$ UI depending on age [1, 6-9].

Major risk factors for UI are age, obesity, pregnancy, type of delivery, birth frequency, menopause, hysterectomy, and social habits $[3,7,10]$. Stress incontinence, urge incontinence and mixed incontinence are the most common types of UI. Stress incontinence occurs due to efforts such as coughing, physical activity, sports activity, and position change. Urge incontinence is characterized by a sudden, strong urge to urinate. Mixed incontinence is the coexistence of both types $[11,12]$.

UI negatively affects the person's health status in physical, social, psychological, and financial aspects. Although it is not life-threatening, it increases anxiety, decreases self-esteem, and causes emotional problems 
up to depression due to the continuous feeling of wetness and irritation $[5,13,14]$. Moreover, UI is not easily expressed by the patient and, therefore, frequently remains untreated. Only one in four women is estimated to claim medical treatment, and about half of them wait 2 to 5 years after the initiation of incontinence. The reasons for a late admission include privacy concerns, insufficient knowledge about the potential treatment options, and perception of the condition as a typical feature of aging and general negligence $[2,15-18]$.

Therefore, women with UI complaints are usually not treated or late for the treatment. To cope with the problem, preventing low extremities from cold, warming the abdominal surface, reducing hydration, avoiding carrying heavy objects, and reducing social life are most frequently chosen as alternatives [19-21].

Healthcare staff, particularly the nurses, have an essential role in determining the UI in the early period [10]. All admissions to a healthcare facility should include a UI assessment even though there is no previous diagnosis of UI. This may help increase women's quality of life and prevent permanent health problems. UI is often ignored in women admitted to hospital with another health problem and it is not mentioned. Our study was conducted to determine the presence of UI, its frequency, coping methods, and its effect on quality of life in women admitted to the hospital with another health problem. In addition, this study aims to determine how important this issue is for healthcare personnel and women. In the present study, we aimed to determine UI prevalence, coping behaviors, and its impact on quality of life among hospitalized middle-aged women.

\section{Material and methods}

In this cross-sectional and descriptive study, we enrolled female patients admitted to Health Sciences University (SBU) Gaziler Physical Therapy and Rehabilitation Training and Research Hospital, Ankara-Turkey between March-July 2019. The main inclusion criteria were the age at or above 40 years knowing Turkish and absence of incontinence as the primary reason for admission. Patients who not able to communicate verbally or who did not provide consent to participate were excluded. The study was conducted following the Declaration of Helsinki, and the protocol was approved by the institutional review board (code: 46418926-19/90, date of approval: 12.03.2019). Participants gave written informed consent.

We collected data using a face-to-face interview method. In the first step, the following standard explanation was made to each participant: "Involuntary incontinence is very frequently in women. This situation may develop due to increased intraabdominal pressure or it may occur without any reason. While women can hold urine easily, it may become impossible over time". Subsequently, the participants were asked, "Are you urinating unintentionally?". Individuals who answered "yes" to this question continued with the study procedures. Those who responded "no" completed the study, but they were given brief advice about preventive measures of UI.

Additional data were collected using a previously established questionnaire $[12,16,17]$ which consisted of two parts. The first part included six questions about the sociodemographic characteristics. The second part included a survey of chronic diseases, obstetric history, and UI. The next step was to administer the Turkish version of The International Consultation on Incontinence Questionnaire Short Form (ICIQSF) developed by Avery et al. Turkish validity and reliability were done by Çetinel et al. ICIQ-SF can be used to evaluate the prevalence, frequency, amount, perceived causes of urinary incontinence and the effect of urinary incontinence on quality of life in all groups, male-female, young-old. Stress incontinence is defined as "I leak urine while coughing, sneezing" and "I leak when I'm moving or doing sports" in determining the UI type. Urge incontinence should be considered if there is a feeling of urgency and inability to reach the toilet, and if both are seen together, mixed incontinence should be considered. The scale has four dimensions. It deals with how often urinary incontinence occurs in the first dimension, the amount of urinary incontinence in the second dimension. The effect of urinary incontinence in the third dimension on daily life and the situations that cause urinary incontinence in the fourth dimension are discussed. The first three dimensions are scored in the evaluation. The answers given to the fourth dimension, which is not scored, are used to determine the type of urinary incontinence based on the individual's complaints. Scoring was done by determining a single score instead of adding the dimension scores separately. A score of eight or higher for the ICIQ-SF score was determined to be the most appropriate cut-off point for irritating urinary incontinence. The scores that can be obtained from the scale range from 0 to 21 . A low score indicates that urinary incontinence has little effect on quality of life, while a high score indicates that it affects the quality of life very much. The cronbach's alpha coefficient of the scale was found to be 0.71 . In this study, the ICIQ-SF cronbach alpha value was calculated as 0.76. ICIQ-SF has four dimensions: frequency, degree, impact on daily life, and precipitating factor of UI. To evaluate the effect of UI on quality of life, scores from the first three dimensions summed up to determine a single score. The Turkish version of the ICIQ-SF was previously validated successfully [11]. The scores that can be obtained from the scale range from 0 to 21 . Higher scores indicate a higher impact of UI on quality of life.

The Incontinence Quality of Life Scale (I-QOL) was also developed by Wagner et al. in 1996 in the United States to determine patients' quality of life with UI [22]. The scale was revised by Patrick et al. [23] in 1999, and psychometric measurements were implemented during the creation of European versions. I-QOL consists of three subdomains, including limitation of behaviors (LB) (items 1, 2, 3, 4, 10, 11, 13, and 20), psychosocial influence (PI) (items 5, 6, 7, 9, 15, 16, 17,21 , and 22) and social isolation (SI) (items 8, 12, 14, 18, and 19). The total score from the three domains is summed up to obtain a single score between 0 and 100 . Higher scores indicate better quality of life. The Turkish validity and reliability of the I-QOL was performed by Özerdoğan and Beji, and the cronbach alpha coefficient was found to be 0.96 [24]. In this study, the I-QOL cronbach alpha value was found to be 0.92 . The validity and reliability of the Turkish version of I-QOL were previously published.

The WHO classification was used for obesity grading in the study [25].

\section{Statistical analysis}

Analyses were performed using the Statistical Package for Social Sciences (SPSS) 20.0 (IBM SPSS Inc., Chicago, IL) software. Categorical variables were compared using the Chi-square tests. Continuous variables were compared using the Student's t-test or the Mann -Whitney U test. Bivariate correlations were evaluated using the Spearman or Pearson correlation analysis. $\mathrm{P}<0.05$ values were considered statistically significant. 


\section{Results}

A total of 140 women were enrolled, and 90 (64.3\%) reported UI problems. Table 1 shows the descriptive characteristics of the study population. The average age of the participants was $60.6 \pm 11.3$ years (40 to 83 years). The majority of the participants $(82.2 \%)$ were married, and a half $(50 \%)$ were primary school graduates, more than half $(55.6 \%)$ were obese, $76.7 \%$ had at least one chronic disease, and $85.6 \%$ were postmenopausal. The most frequent delivery type was vaginal.

Table 2 shows the data related to UI. Around one-third (37.8\%) had UI complaints for 2-4 years, and 44.4\% for more than five years. Stress and mixed type were recorded as $47.8 \%$ and $34.4 \%$, respectively. UI was persistent in $21.1 \%$ and $2-3$ times/week in $37.8 \%$ of the participants. The severity of UI was moderate to severe in half of the sample. Up to two-third of UI occurred during sneezing/coughing or urging.

Awareness of UI, the impact of UI on daily life, and coping methods are shown in Table 3. The mean score of women's UI effect on daily life was found to be $5.0 \pm 2.5$. The majority of the participants $(64.4 \%)$ considered UI a health issue, but a similar proportion $(62.9 \%)$ did not claim professional help.

\section{Table 1}

Introductory characteristics of women, chronic disease status, obstetrics and gynecological characteristics $(n=90)$

\begin{tabular}{|c|c|c|}
\hline Variables & $\mathrm{N}$ & $\%$ \\
\hline \multicolumn{3}{|l|}{ Presence of UI $(n=140)$} \\
\hline Urinary incontinence & 90 & 64,3 \\
\hline Without incontinence & 50 & 35,7 \\
\hline \multicolumn{3}{|l|}{ Age (year) } \\
\hline $40-49$ & 22 & 24,4 \\
\hline $50-59$ & 17 & 18,9 \\
\hline $60-69$ & 30 & 33,4 \\
\hline 70 and above & 21 & 23,3 \\
\hline $\mathrm{X} \pm \operatorname{Min} / \mathrm{Max}$ & \multicolumn{2}{|c|}{$60,6 \pm 11,3$} \\
\hline \multicolumn{3}{|l|}{ Marital Status } \\
\hline Married & 74 & 82,2 \\
\hline Single & 16 & 17,8 \\
\hline \multicolumn{3}{|l|}{ Education Status } \\
\hline Literate & 21 & 23,3 \\
\hline Primary education & 45 & 50,0 \\
\hline High school & 16 & 17,8 \\
\hline University & 8 & 8,9 \\
\hline \multicolumn{3}{|l|}{ BMI $(\mathrm{kg} / \mathrm{m} 2)$} \\
\hline Normal weight & 9 & 10,0 \\
\hline Over-weight & 7 & 7,8 \\
\hline Obese & 50 & 55,6 \\
\hline Morbidly obese & 24 & 26,6 \\
\hline \multicolumn{3}{|l|}{ Chronic illness* } \\
\hline Have & 69 & 76,7 \\
\hline Don't Have & 21 & 23,3 \\
\hline \multicolumn{3}{|l|}{ Number of births } \\
\hline $0-2$ & 24 & 26,6 \\
\hline 3 & 26 & 28,9 \\
\hline$\geq 4$ & 40 & 44,5 \\
\hline \multicolumn{3}{|l|}{ Mode of birth } \\
\hline Vaginal & 78 & 87,6 \\
\hline Caesarean section & 11 & 12,4 \\
\hline \multicolumn{3}{|l|}{ Menopausal status } \\
\hline Yes & 77 & 85,6 \\
\hline No & 13 & 14,4 \\
\hline
\end{tabular}

Urinary Incontinence (Ui) Minimum (Min)- Maximum (Max) Body Mass Index (BMI)

* The "n" is folded because more than one option is answered

\begin{tabular}{|c|c|c|}
\hline Variables & $\mathrm{N}$ & $\%$ \\
\hline \multicolumn{3}{|l|}{ Duration (year) } \\
\hline 1 & 16 & 17,8 \\
\hline $2-4$ & 34 & 37,8 \\
\hline $5-7$ & 20 & 22,2 \\
\hline$\geq 8$ & 20 & 22,2 \\
\hline Mean (min-max) & & $4(1-20)$ \\
\hline \multicolumn{3}{|l|}{ Types } \\
\hline Urge & 11 & 12,2 \\
\hline Stress & 43 & 47,8 \\
\hline Mixed & 31 & 34,4 \\
\hline No apparent reason & 5 & 5,6 \\
\hline \multicolumn{3}{|l|}{ Urinary incontinence frequency } \\
\hline Once a week or less & 28 & 31,1 \\
\hline Two or three times a week & 34 & 37,8 \\
\hline Once a day & 9 & 10,0 \\
\hline Always & 19 & 21,1 \\
\hline \multicolumn{3}{|l|}{ The amount of urinary incontinence } \\
\hline Little & 45 & 50,0 \\
\hline Moderate & 35 & 38,9 \\
\hline Much & 10 & 11,1 \\
\hline \multicolumn{3}{|l|}{ Urinary incontinence status * } \\
\hline While coughing / sneezing & 58 & 64,4 \\
\hline While going to the toilet & 42 & 46,7 \\
\hline While on the move & 40 & 44,4 \\
\hline While getting dressed after the toilet & 16 & 17,8 \\
\hline While sleeping & 7 & 7,8 \\
\hline
\end{tabular}

Urinary Incontinence (Ui) Minimum (Min)- Maximum (Max)

* The " $n$ " is folded because more than one option is answered

The reason for not claiming any help varied and mixed (Table 3). The average time to the first admission from the initial UI symptoms was 18 months $(n=34)$. Regarding the coping behaviors with UI, $82.8 \%$ reported changing underwear frequently, followed by using pads/diapers, restricting fluid intake, and keeping feet warm.

Table 4 shows I-QOL scores. The average score was $85.0 \pm 14.7$ from the "Psychosocial influence" sub-dimension, $71.0 \pm 16.9$ from the "Social isolation" sub-dimension, $65.1 \pm 16.6$ from the "Limitation of behaviors" sub-dimension, and $74.6 \pm 14.5$ from the whole scale.

The data in Table 5 emerged as a result of the analysis carried out to determine whether there is a correlation between some characteristics of women and the I-QOL scale and its sub-dimensions. Accordingly, a negative, moderate $(\mathrm{r}=-0.379)$ and statistically significant correlation was found between age and I-QOL total score. $(\mathrm{p}<0.001)$. In addition, a statistically significant difference was found between age and all I-QOL subscales (respectively, $\mathrm{p}=0.001, \mathrm{p}=0.004, \mathrm{p}=0.002$ ).

A negative, moderate $(\mathrm{r}=-0.262)$ and statistically significant correlation was found between body mass index (BMI) and I-QOL total score $(p=0.013)$. In addition, a statistically significant difference was found between the BMI and I-QOL subscales in terms of behavior restriction score and social isolation score (respectively, $\mathrm{p}=0.001, \mathrm{p}=0.005$ ).

A statistically significant difference was found in terms of I-QOL total score, behavior restriction score and social isolation score among groups formed according to the number of births (respectively , $\mathrm{p}=0.025, \mathrm{p}=0.002, \mathrm{p}=0.029$ ).

A negative, moderate $(\mathrm{r}=-0.254)$ and statistically significant $(p=0.016)$ correlation was found between the duration of UI 
The level of UI affecting the daily life of women, the characteristics of $\mathrm{Ul}$ about being aware of and coping with UI $(n=90)$

\begin{tabular}{|c|c|c|}
\hline \multicolumn{3}{|l|}{ Variables } \\
\hline \multicolumn{3}{|l|}{ Level of influence on daily life } \\
\hline $\mathrm{X} \pm \mathrm{SD}$ & \multicolumn{2}{|c|}{$5,0 \pm 2,5$} \\
\hline Mean (min/max) & \multicolumn{2}{|c|}{$4(1-10)$} \\
\hline Status of seeing UI as a health problem & $\mathrm{N}$ & $\%$ \\
\hline Yes & 58 & 64,4 \\
\hline No & 32 & 35,6 \\
\hline \multicolumn{3}{|l|}{ Status of applying to a health care facility } \\
\hline Yes & 34 & 37,1 \\
\hline No & 56 & 62,9 \\
\hline \multicolumn{3}{|c|}{ Reasons for not applying to a health care facility $*(n=56)$} \\
\hline Disregard & 51 & 91,1 \\
\hline Seeing as a normal situation & 36 & 64,3 \\
\hline Not wanting to disturb the healthcare staff & 28 & 50,0 \\
\hline $\begin{array}{l}\text { Refraining from being examined and being } \\
\text { embarrassed }\end{array}$ & 25 & 44,6 \\
\hline Thinking that there is no cure & 17 & 30,4 \\
\hline Not having time & 7 & 12,5 \\
\hline \multicolumn{3}{|l|}{ Coping behaviors with UI * $(\mathrm{n}=90)$} \\
\hline Frequently changing underwear & 74 & 82,2 \\
\hline Using pads and cloths & 54 & 60,0 \\
\hline Reducing fluid intake & 53 & 58,9 \\
\hline Keeping feet warm & 42 & 46,7 \\
\hline Taking care not to lift heavy & 14 & 15,6 \\
\hline Cleaning the genital area with hot water & 11 & 12,2 \\
\hline Seating on hot brick & 7 & 7,8 \\
\hline Applying hot water to the stomach & 6 & 6,7 \\
\hline \multicolumn{3}{|c|}{$\begin{array}{l}\text { Duration of application to health institution after UI complaints (month) } \\
(\mathrm{n}=34)\end{array}$} \\
\hline $\mathrm{X} \pm \mathrm{SD}$ & \multicolumn{2}{|c|}{$18,4 \pm 15,4$} \\
\hline Mean (min/max) & \multicolumn{2}{|c|}{$12(3-60)$} \\
\hline
\end{tabular}

Urinary Incontinence (Ui) Minimum (Min)- Maximum (Max)

Standard deviation (SD)

* The " $\mathrm{n}$ " is folded because more than one option is answered

Table 4

\begin{tabular}{lllll}
\hline I-QOL and its sub-dimensions & $\bar{x}$ & SD $( \pm)$ & Min. & Max. \\
\hline Total I-QOL survey score & 74,6 & 14,5 & 30,0 & 99,1 \\
\hline Sub dimensions & & & & \\
Psychosocial influence & 85,0 & 14,7 & 33,3 & 100,0 \\
Social Isolation & 71,0 & 16,9 & 24,0 & 100,0 \\
Limitation of behavior & 65,1 & 16,6 & 25,0 & 97,5 \\
\hline
\end{tabular}

Incontinence Quality of Life Scale (I-QOL)

\section{Table 5}

Correlation analysis between some characteristics of women and I-QOL $(n=90)$

\begin{tabular}{|c|c|c|c|c|c|}
\hline \multirow{3}{*}{$\begin{array}{l}\text { Variables } \\
\text { Age* }\end{array}$} & & I-QOL Total & I-QOL DS & I-QOL PE & I-QOL SI \\
\hline & $\mathrm{R}$ & $-0,379$ & $-0,403$ & $-0,300$ & $-0,328$ \\
\hline & P & $<0.001$ & $<0.001$ & 0.004 & 0.002 \\
\hline \multirow[t]{2}{*}{ BMI* } & $\mathrm{R}$ & $-0,262$ & $-0,335$ & $-0,110$ & $-0,290$ \\
\hline & P & 0.013 & 0.001 & 0.303 & 0.005 \\
\hline \multirow{2}{*}{$\begin{array}{l}\text { Number of } \\
\text { births }{ }^{* *}\end{array}$} & $\mathrm{R}$ & $-0,263$ & $-0,264$ & $-0,150$ & $-0,257$ \\
\hline & $\mathrm{P}$ & 0.012 & 0.012 & 0.159 & 0.014 \\
\hline \multirow[t]{2}{*}{ Durtaion of UI** } & $\mathrm{R}$ & $-0,254$ & $-0,226$ & $-0,188$ & $-0,278$ \\
\hline & $\mathrm{P}$ & 0.016 & 0.032 & 0.075 & 0.008 \\
\hline \multirow{2}{*}{$\begin{array}{l}\text { Urinary } \\
\text { incontinence } \\
\text { frequency } * *\end{array}$} & $\mathrm{R}$ & $-0,616$ & $-0,528$ & $-0,551$ & -0600 \\
\hline & $P$ & $<0.001$ & $<0.001$ & $<0.001$ & $<0.001$ \\
\hline
\end{tabular}

DS: Limitation of Behavior, SI: Social Isolation, PE:Psychosocial Influence * Pearson correlation test ** Spearman correlation test and I-QOL total score. In addition, a statistically significant difference was found between the duration of UI and the I-QOL subscales in terms of behavior restriction score and social isolation score (respectively, $\mathrm{p}=0.032, \mathrm{p}=0.008$ ).

Although not shown in the table, no significant relationship was found between educational status, marital status, perception of income status, chronic disease status, mode of delivery, menopause status and I-QOL total score. In addition, it was determined that the I-QOL scale scores decreased as the age increased (40-49 age $82.9 \pm 11.19 ; 50-59$ age $77.3 \pm 10.7 ; 60-69$ age $71.8 \pm 14.0 ; 70$ and over age $67.6 \pm 16.7$ ).

\section{Discussion}

UI is a serious condition that often impacts all areas of women's life and its frequency increases with age. However, most women do not get treated on time. In our study, UI was detected in $64.3 \%$ of women aged 40 years or older admitted to hospital for reasons other than UI, indicating that the frequency of UI is relatively high, but it remains unreported. These results show that healthcare personnel should question the presence of UI in all women for whatever reason they are admitted to the hospital.

The etiology of UI among women is often mixed. Aging, comorbid chronic diseases, and multiple deliveries are among the most frequently addressed related factors. Although UI may be diagnosed in the young and middle-aged population, bladder contractility, capacity, and ability to delay urination decrease with increasing age. The frequency UI was found $58.4 \%$ between the ages of $40-50$ years, and $30-60 \%$ over the age of 65 in previous studies [6-9]. In our study, $24.4 \%$ of women between the ages of $40-49$ and $56.7 \%$ of women aged 60 and over had UI. As stated in the literature, incontinence is a problem that increases in frequency with advancing age and affects individuals in many dimensions. According to the results of our study, it was found that women's quality of life scale scores decreased as age increased. These results are very important in terms of showing that women's quality of life decreases due to incontinence.

Among other risk factors of UI are BMI, type of delivery, and menopause $[3,26]$. We found that $90 \%$ of the participants were overweight, $76.7 \%$ had a chronic disease, $73.4 \%$ had three or more deliveries, $87.6 \%$ had vaginal deliveries, and $85.6 \%$ in the menopause period. The relationship between UI and some risk factors has been shown in many studies. Gözükara et al. found that chronic diseases and menopause increased the risk of UI 1.8 and 2.7 times, respectively [27]. Thubert et al. reported that the relative risk of UI in morbidly obese women was five times higher than non-obese women, and 10\% weight loss reduced the frequency of urinary leakage by $50 \%$ [28]. These results indicate that women with obesity, chronic diseases, multiple delivery history, and menopause are more likely to experience UI.

The average duration of UI for women participating in the study was four years, while $44.4 \%$ had UI for five years or more. Previously, Acar and Yurtsever reported that, among 124 women aged 65 and over with UI complaints, $29.8 \%$ had UI for $1-3$ years, $21 \%$ for $4-6$ years, $28.2 \%$ for seven years or more [13]. In another study, however, Demir and Beji [2] observed that the longest duration of incontinence was one year (24.3\%), while Kok et al. [16] identified $14.11 \%$ of the patients had UI complaints for at least eight years. It should be noted that many women live with UI as it is a normal part of daily life for a long time.

We identified that stress (47.8\%) and mixed (34.4\%) type UI were the most among our study population. Similar findings from different populations exist in the literature. Skyes et al. [29], 
Karaca and Nur Demir [30], found that the frequency of mixed incontinence was the highest. However, studies conducted in the community and hospitalized individuals in Turkey, Japan, and Sweden have reported that stress UI occurs more frequently than other types (35.9\% to $46 \%$ ) [31-33], consistent with the current study.

In our study, $37.8 \%$ of the participants had UI two or three times a week, $10 \%$ once a day, and $12.2 \%$ persistently. In addition, half of the women had moderate to large amounts of urine leakage. These results confirm the previous studies conducted by Kocak et al., who found that $45.9 \%$ had UI less than twice a week, $17.4 \%$ 2-3 times a week, 9.9\% every day, $13.2 \%$ several times a day, and $13.6 \%$ more frequently [7], Demir and Beji who reported $41.8 \%$ of women had UI once a week or less, $33.2 \%$ 2-3 times a week, $15.1 \%$ once a day, $9.9 \%$ a few times a day [2].

The consequences of UI include physical, social, and psychological issues. However, different studies have shown that only one-fourth of women seek help, and most women take no action $[8,34,35]$. Our findings in the present study indicated that the duration of UI was on average four years, and the daily life of women was moderately affected ( $\pm \mathrm{SS}: 5.0 \pm 2.5)$. Nevertheless, $64.4 \%$ of the participants stated that they did not consider it a health issue and did not claim help $(62.9 \%)$. Considering the results of our study, individuals stated that they do not care about this situation to a large extent $(91.1 \%)$ and they see it as normal $(64.3 \%)$. In addition, they stated that they don't want to disturb the healthcare personnel for this problem (50\%), they are embarrassed to be examined $(44.6 \%)$, and they thought that there is no treatment (30.4\%). These findings suggest that women change their lifestyle instead of receiving professional care to cope with UI. This is confirmed by the fact that those admitted to the hospital mentioned their complaints were present for an average of one year. The average I-QOL score of individuals with incontinence was $74.6 \pm 14.5$, and it was seen that their quality of life was negatively affected. In the study conducted by Koçak et al. on 1012 women over the age of 18, they found that the mean ICIQ-SF of those with UI was 10.26 [7]. In the study of Ceyhan et al., it was determined that the mean ICIQ-SF score of the individuals was $10.65 \pm 4.40$ and $80.9 \%$ of them experienced urinary incontinence at an uncomfortable level. All these results show strikingly that UI negatively affects the lives of individuals as age increases.

The reasons for ignoring professional help have been previously reported, including the belief that it is normal for the age, privacy concerns, and perception of no cure [34-36]. In our study, the reasons for no admission for care were consistent with the literature. Concerning the coping behaviors of the participants, most patients reported changing underwear more frequently, pad/diaper use, and fluid restriction. Similar findings were reported by Saleh et al. [37], who reported that women took frequent showers, used pads, changed underwear frequently, and took measures such as reducing fluid intake as a coping behavior. Moreover, Demir and Beji [2] determined that women took precautions such as changing underwear frequently, used pads/ diapers, kept the body warm, and avoided lifting heavy work. The present study and previous works have shown that women do not use pelvic muscle exercises (KEGEL) recommended for the treatment of UI $[17,38]$.

Coping behaviors with UI impact women's physical, mental and social health, home, work, and sexual life and reduce the overall quality of life. In the current study, the participants had moderate quality of life scores. Quality of life was most negatively affected by psychosocial influences, social isolation, and limitation of behaviors. There was a statistically significant relationship between age, BMI, number of deliveries, frequency of UI and duration of UI, and quality of life. Similarly, in community-based and hospital-based studies, UI was reported to negatively affect women's quality of life at a mild-moderate level [30-32]. Various studies have shown that increasing age, BMI, number of deliveries, frequency, and duration of UI negatively affect the quality of life [31,32].

It was determined that the quality of life of the individuals in the study due to incontinence was affected in the subdimensions. It was determined that the mean of limiting behaviors $65.1 \pm 16.6$, psychological impact $85.0 \pm 14.7$ and social isolation $71.0 \pm 16.9$ points were seriously affected. In the study of Ceyhan et al., I-QOL sub-dimension and total score averages were found to be seriously affected by limiting behaviors $20.00 \pm 4.83$, psychological effects $29.04 \pm 3.78$, and social isolation $13.52 \pm 3.83$ points and overall I-QOL total scores were determined as $63.39 \pm 11.26$ [39]. This shows that incontinence is a problem that negatively affects the quality of life of women, socially, behaviorally and psychologically, in all areas of the woman's life.

This study has some limitations. First, the sample consists of women over 40 years of age who were admitted to a tertiary care facility in a single center. Therefore, it does not reflect male patients, the general public, and younger aged individuals. Second, UI was determined using subjective assessment.

In conclusion, UI is common among women middle-aged women. Stress type UI was the most common, and the complaints were associated with mixed etiology. Most women do not claim professional help shortly after their symptoms start. UI impacts women's quality of life from many aspects. Evidence-based qualitative and quantitative studies are needed to increase the awareness of women about UI.

\section{References}

1. Bilgiç D, Bejı NK, Özbaş A, Çavdar İ, et al. Coping and help-seeking behaviors for management of urinary incontinence. LUTS. 2017;9, 9(3), https://doi: 10.1111/luts.12120.

2. Demir S, Beji NK. Üriner inkontinanslı kadınlarda yaşam kalitesi ve sağlık arama davranışları. F.N. Hem. Derg. 2015; 23(1), 179-182. https://doi: 10.17672/fnhd.68821

3. Chughtai B, Thomas D, Russell D, et al. Prevalence of and risk factors for urinary incontinence in home hospice patients. Eur Urol. 2018; 75(2), 268-271 https://doi: 10.1016/j.eururo.2018.10.027.

4. Poomalar GK, Priyadharshini M. Prevalence of urinary incontinence in reproductive women and its impact on quality of life. IJRCOG.2015;4(5), https://dx.doi.org/10.18203/2320-1770.ijrcog20150710

5. Seshan V. Coping strategies \& self measures adopted by the women with urinary incontinence \& its effects on QOL. Obstet Gynecol Int J. 2016; 5(7): 00187. https://doi: 10.15406/ogij.2016.05.00187

6. Demirci N, Aba YA, Süzer F, et al. 18 yaş üstü kadınlarda üriner inkontinans ve yaşam kalitesine etkileri. Fırat Sağllk Hizmetleri Dergisi. 2012;7(19),23-37: https://www.researchgate.net/publication/311274185

7. Koçak İ, Okyay P, Dündar M, et al. Female urinary incontinence in the west of Turkey: Prevelance, risk factors and impact on quality of life. Eur Urol. 2005;48(4):634-41. https://pubmed.ncbi.nlm.nih.gov/15963633/ 
8. Öztürk GZ, Toprak D, Basa E. 35 yaş üzeri kadınlarda üriner inkontinans sıklığı ve etkileyen faktörlerin değerlendirilmesi. Şişli Etfal Hastanesi Tıp Bülteni. 2012; 46: 170-6.

9. Yücel Ü, Hadımlı A, Çakır-Koçak Y, et al. Bornova'da yaşayan 20 yaş ve üzeri kadınlarda üriner inkontinans prevelansı ve risk faktörleri. Arch Health Sci Res. 2018; 5: 414-423. https://doi: 10.17681/hsp.385265

10. Öz Ö, Altay B. Üriner inkontinans risk faktörleri ve hemşirelik yaklaşımı. İnönü Üniversitesi Sağllk Bilimleri Dergisi. 2017; 6 (1), 34-37.

11. Çetinel B, Özkan B, Can G. [The validation study of ICIQ-SF Turkish version]. Türk Üroloji Derg. 2004;30(3):332-8.

12. Akkuş Y. 18 yaş üstü kadınlarda üriner inkontinans sıklığı, tipi, şiddeti, risk faktörleri ve yaşam kalitesine etkisinin değerlendirilmesi. Yüksek Lisans Tezi, Yıldırım Beyazıt Üniversitesi Sağlık Bilimleri Enstitüsü, Hemşirelik Anabilim Dalı. 2014.

13. Acar NB. Üriner inkontinansı olan yaşlı kadınlarda yaşam kalitesi ve depresyon arasındaki ilişki. Yükseklisans Tezi, Mersin Üniversitesi Sağlık Bilimleri Enstitüsü, Hemşirelik Anabilim Dalı. 2010.

14. Ghafouri A, Alnaimi AR, Alhothi HM, et al. Urinary incontinence in Qatar: A study of the prevalence, risk factors and impact on quality of life. Arab J Urol. 2014; 12(4): 269-274. https://doi.org/10.1016/j.aju.2014.08.002

15. Howard F, Steggall M. Urinary incontinence in women: Quality of life and help-seeking. Br J Nurs. 2010; 19(12):742-749. https://doi 10.12968/bjon.2010.19.12.48651.

16. Kök G, Şenel N, Akyüz A. GATA jinekoloji polikliniğine başvuran 20 yaş üstü kadınların üriner inkontinans açısından farkındalık durumlarının değerlendirilmesi. Gülhane Tip Dergisi. 2006; 48(3), 132-136.

17. Göral S. Akdeniz bölgesi huzurevlerinde yaşayan kadınlarda üriner inkontinans ve yaşam kalitesi. Yükseklisans Tezi, Akdeniz Üniversitesi Sağlık Bilimleri Enstitüsü, Hemşirelik Anabilim Dalı. 2014.

18. Wojtowicz U, Płaszewska-Zywko L, Stangel-W' ojcikiewicz 'K, Basta A. Barriers in entering treatment among women. Ginekol Pol. 2014; 85(5) doi: 10.17772/gp/1734.

19. Delarmelindo RCA, Parada CMCGL, Rodrigues RAP, Bocchi SCM. Women's strategies for coping with urinary incontinence. Rev Esc Enferm USP[İnternet]. 2013;47(2):296-303. http://www.scielo.br/pdf/reeusp/v47n2/en_04.pdf

20. Ertem G. Üriner inkontinanslı hastaların hastalığıyla başa çıkma yollarının incelenmesi. Uluslararası Insan Bilimleri Dergisi. 2009; $6(1), 177-187$

21. Li FL, Low LP, Lee DT. Chinese women's experiences in coping with urinary incontinence. J Clin Nurs. 2007;16(3):610-2. https://doi 10.1111/j.1365-2702.2006.01755.x. PMID: 17335537

22. Wagner TH, Patrick DL, Bavendam TG, Martin ML, Buesching DP. Quality of life of persons with urinary incontinence: development of a new measure. Urology. 1996;47(1):67-71; discussion 71-2https://doi 10.1016/s0090-4295(99)80384-7. PMID: 8560665.

23. Patrick DL, Martin ML, Bushnell DM, Yalcin I, Wagner TH, Buesching DP. Quality of life of women with urinary incontinence: further development of the incontinence quality of life instrument (I-QOL). Urology. 1999;53(1):71-6. https://doi 10.1016/s00904295(98)00454-3. Erratum in: Urology 1999;53(5):1072. PMID: 9886591.

24. Özerdoğan NÖ, Beji NK. Eskisehir, Bilecik, Afyon, Kütahya illerinde 20 yaş ve üstü kadınlarda üriner inkontinansın prevalansı, risk faktörleri, yaşam kalitesine etkisi. Florence Nightingale Hemşirelik Dergisi. 2003; 13(51):37-50.

25. Organization WH. Physical status: The use of and interpretation of anthropometry, Report of a WHO Expert Committee. World Health Organization; 1995.

26. Nygaard CC, Schreiner L, Morsch TP, Saadi RP, Figueiredo MF, Padoin AV. Urinary Incontinence and Quality of Life in Female Patients with Obesity. Rev Bras Ginecol Obstet. 2018;40(9):534-539. English. doi: 10.1055/s-0038-1670626. Epub 2018 Sep 19. PMID: 30231292.

27. Gözükara F, Koruk I, Kara B. Urinary incontinence among women registered with a family health center in the Southeastern Anatolia Region and the factors affecting its prevalence. Turk J Med Sci. 2015;45(4):931-9. doi: 10.3906/sag-1410-31. PMID: 26422870.

28. Thubert T, Deffieux X, Letouzey V, Hermieu JF. Obesity and urogynecology: a systematic review. Prog Urol. 2012;22(8):445-53. French. doi: 10.1016/j.purol.2012.03.009. Epub 2012 May 30. PMID: 22732579.

29. Sykes D, Castro R, Pons ME, Hampel C, et al. Characteristics of female outpatients with urinary incontinence participating in a 6-month observational study in 14 European countries. Maturitas. 2005; 30(52), https://doi.org/10.1016/j.maturitas.2005.09.003

30. Karaca BŞ, Demir AN. Üriner inkontinansın kadın hastalarda yaşam kalitesi ve duygu durum üzerine etkisi ve hastaların egzersiz farkındalık düzeyleri. Med. J. Ankara Tr. Res. Hosp. 2019; 52(2), 133-137.

31. Kocaöz S, Talas MS, Atabekoğlu CS. Urinary incontinence among Turkish women: An outpatient study of prevalence, risk factors, and quality of life. J Wound Ostomy Continence Nurs. 2012;39(4):431-9. https://doi 10.1097/WON.0b013e318259c42b.

32. Lasserre A, Pelat C, Guéroult V, Hanslik T, et al. Urinary incontinence in french women: prevalence, risk factors, and impact on quality of life. Eur Urol. 2009; 56(1), https://doi.org/10.1016/j.eururo.2009.04.006

33. Samuelsson E, Victor A, Svärdsudd K. Determinants of urinary incontinence in a population of young and middle-aged women. Acta Obstet Gynecol Scand. 2000; 79(3), https://doi.org/10.1034/j.1600-0412.2000.079003208.x

34. Hägglund D, Walker-Engström LM, Larsson G, Leppert J. Reasons why women with long-term urinary incontinence do not seek professional help: A cross-sectional population-based cohort study. Int Urogynecol J Pelvic Floor Dysfunct. 2007; 14(5), https://doi $10.1007 / \mathrm{s} 00192-003-1077-9$

35. Horrocks S, Somerset M, Stoddart H, Peters TJ. What prevents older people fom seeking treatment for urinary incontinence? Aqualitative exploration of barriers to the use of community community continence services. Family Practice. 2004; 21(2), https://doi.org/10.1093/ fampra/cmh622

36. Kang Y, Crogan NL. Social and cultural construction of urinary incontinence among Korean-American elderly women. Geriatr Nurs. 2008; 29(2). doi: 10.1016/j.gerinurse.2008.01.002. PMID: 18394511.

37. Saleh N, Bener A, Khenyab N, Al-Mansori Z, Al Muraikhi A. Prevalence, awareness and determinants of health care-seeking behaviour for urinary incontinence in Qatari women: A neglected problem?. Maturitas. 2005; 50(1). doi: 10.1016/j.maturitas.2004.04.003

38. Güvenç G, Kocaöz S, Kök G. Quality of life in climacteric Turkish women with urinary incontinence. Int J Nurs Pract. 2016;22(6):649659. https://doi.org/10.1111/ijn.12495

39. Ceyhan Ö, Göriş S, Zincir H. Yaşlı bireylerde uykuyu etkileyen önemli bir problem:inkontinans. Sağlık Bilimleri Dergisi (Journal of Health Sciences). 2018; 27(1): 29-35. 